Egyptian Journal of Rabbit Science, 26(1): 121 - 134 (2016)

\title{
RELATIONSHIP BETWEEN LIPTEN HORMONE CONCENTRATION AND RABBITS REPRODUCTIVITY
}

\author{
I.M. El-Werdany ${ }^{\text {I }}$;.F.A. Saleh ${ }^{2}$; T.S.T. Seleem ${ }^{2}$; A.M.F. Khadr ${ }^{2}$ and \\ A.M. Hasan ${ }^{1}$ \\ 1- Poultry Production Department, Faculty of Agriculture, Ain Shams \\ University, Qalubia, Egypt. \\ 2- Rabbit Breeding Research Department, Animal Production Research \\ Institute, Dokki, Giza, Egypt. \\ E-mail of corresponding author: noha_medo@yahoo.com
}

The present work was planned to study the relationship between Lipten hormone concentration and rabbit reproductivity. Two rabbit breeds (Baladi Black as a native breed and New-Zealand White as an exotic breed) were used in the present study. Lipten hormone concentrations were determined in blood, milk and semen of ordinary and low fertile rabbits.

The study included two experiments. Primary experiment was conducted to determine the high and low fertile doe and buck rabbits. The second experiment was planned to measure Lipten hormone concentration in blood serum of high and low fertile doe and buck rabbits. Lipten hormone levels were also measured in milk and semen of lactating doe and buck rabbits, respectively.

Sixty sexually mature rabbits (30 in each of low-fertile and highfertile) of twelve months of age (10 does \& 5 bucks within each breed of Baladi Black "BB" and New-Zealand White "NZW") were used in this study.

Results Obtained showed that,blood swrum Leptin hormone concentration in of high fertile doe and buck rabbits were significantly $(P \leq 0.5$ or 0.1$)$ higher than those in low fertile ones, in both two breeds $(B B$ and NZW) rabbits. In each status studied, high and low fertile, and doe and buck rabbits, BB rabbits recorded leptin hormone levels insignificantly higher than those obtained by NZW rabbits.

High fertile BB and NZW lactating rabbit does produced milk with Leptin hormone concentration significantly $(P \leq 0.5$ or 0.1$)$ higher than recorded by low fertile rabbits, during nursing period up to 5 weeks. Semen ejaculated by high fertile BB and NZW rabbit bucks 
contained Leptin hormone levels more significantlyhigher $(P \leq 0.5$ or 0.1) than those of low fertile bucks.

Coclusively, it could be concluded that, there was strongly correlation between Leptin hormone concentration in blood, semen and milk and rabbit reproductivity. BB rabbits recorded Leptin hormone levels insignificantly higher than those of NZW rabbits, so $B B$ rabbits may be characterized by reproductive capability more than NZW rabbits.

Key words: Rabbit; Leptin; fertility; blood; semen; milk.

Developing countries like Egypt are often suffered from protein deficiency. This is due to two main factors. The first is the small number of existing farm animals as compared to rapid growth of human population, and the second is the low productive and reproductive capabilities of these animals (Daader and Seleem, 1999 and Rowida et al., 2010).

The increase in animal protein production may come from short-life cycle animals kept by the small holder farmers such as rabbits (Galal and Khalil, 1994). Rabbit industry is the hope can display an essential role in solving a part of meat shortage and minimizing the gap between requirement and available of the animal protein for human consumption (Zaki et al., 2000; Seleem et al., 2006 and 2007 and Rowida and Seleem, 2007). So, rabbits had gradually increased attention in the last few months for meat production.

Zhang et al. (1994) demonstrated that, Lipten has additional physiological activities, including activation of the sympathetic nervous system, regulation of reproductive function, and activation of the immune system. In human; Houseknecht et al. (1997) reported that, Lipten concentrations in whole and skim milk were correlated with maternal plasma Lipten concentrations. In sheep circulating lipten levels increased from early tomid pregnancy and remained elevated until late pregnancy

Therefore, the aim of the present work was to evaluate the relationship between Lipten hormone levels and rabbit reproductivity, using Baladi Black as a native breed and New-Zealand White as an exotic breed.

\section{MATERIALS AND METHODS}

The present study was conducted in the Department of Poultry Production, Faculty of Agriculture, Ain Sham University, Qalubia, Egypt, in 
partnership with Department of Rabbit, turkey and Waterfowl Breeding Research, Animal Production Research Institute, AgriculturalResearch Center, Dokki, Giza, Egypt. The experimental work was carried out in an Industrial Rabbitry of International IBEX company, near Sakara city, Giza Province, Egypt. The study lasted three months, during the period from January till March.

\section{Experimental animals}

Sixty sexually mature rabbit 30 for each low fertile and high (high _fertile) of twelve month of age (10 does 5 bucks within each breed were used in this study.

Animals were healthy and clinically free of external and internal parasites. Body weight of each animal was recorded twice monthly to make sure that, the animals were healthy.Rabbits were fed ad libitum a commercial diet according to NRC (1994). Ingredients and chemical composition of the pelleted rations are shown in Table 1. Rabbits were raised in semi-closed Rabbitry with wire-netted windows on their sides for providing natural ventilation. The windows were oriented with an elevation of 2 meters from the floor. The floor was made from concrete and have moderately slope (from the middle to both sides) to facilitate water drainage towards a large gutter outside the Rabbitry. During winter and windy days, windows were covered with canvas cloth for protecting rabbits from severe atmosphere especially at night. Rabbits were housed separately in individual wired-cages and arranged in double-tier batteries along the Rabbitry. Cage of each doe (maternity cage) was provided with a metal nest box for kindling and nursing her young, during the suckling period. All cages were equipped with feeders (made of galvanized steel sheets) and have nipples (automatic drinkers). The system provided animals with fresh water and diet which were offered ad libitum all over the experimental period. During the experimental work, the Rabbitry was lit artificially 16 hours daily. Rabbits were kept under similar management system.

\section{The experimental work:}

\section{Experiment 1:}

Primary experiment was conducted to determine the high and low fertile of both doe and buck rabbits. The experiment was designed to separate low-fertile does from high-fertile ones of BB and NZW rabbits. The separation depended on the records in Rabbitry represented in rates of each of 
Table 1. The ingredients and chemical composition of thepellet expermental ration

\begin{tabular}{|c|c|c|c|}
\hline Ingredients & $(\%)$ & \multicolumn{2}{|c|}{$\begin{array}{c}\text { Vitamins \& Minerals premix } \\
\text { per Kilogram. }\end{array}$} \\
\hline Clover hay & 40.50 & Vit.A (IU) & 10000 \\
\hline Wheat bran & 25.00 & Vit.D3 (IU) & 9000 \\
\hline Yellow corn & 14.00 & Vit.E (IU) & 10000 \\
\hline Soybean meal (44\%) & 11.00 & Vit.K (IU) & 3 \\
\hline Molasses & 3.00 & Vit.B1 (IU) & 2 \\
\hline Vinass & 3.00 & Vit.B2 (IU) & 6 \\
\hline Bone meal & 1.75 & Vit.B6 (IU) & 2 \\
\hline Lime stone & 0.70 & Biotin (mg) & 0.2 \\
\hline Sodium chloride & 0.55 & Choline (mg) & 1200 \\
\hline Vitamins \& Mineral Premix & 0.35 & Niacine (mg) & 40 \\
\hline DL-Methionine & 0.15 & $\mathrm{Zn} .(\mathrm{mg})$ & 60 \\
\hline Total & 100 & $\mathrm{Cu} .(\mathrm{mg})$ & 0.1 \\
\hline \multicolumn{2}{|c|}{ Calculated chemical composition $* *$} & Mn. (mg) & 85 \\
\hline Crudeprotein $(\mathrm{CP}) \%$ & 18.00 & Fe. $(\mathrm{mg})$ & 75 \\
\hline Ether extract (EE)\% & 3.00 & Folic acid (mg) & 5.0 \\
\hline Crude fiber $(\mathrm{CF}) \%$ & 14.00 & Pantothenic acid (mg) & 20 \\
\hline Digestible energy $(\mathrm{Kcal} / \mathrm{Kg}$ ) & 2720.00 & & \\
\hline
\end{tabular}

** Calculated according to NRC (1994) for rabbits.

abortion, conception and kindling and values of each of litter size and weight at birth and at weaning, in addition to bunny weight at birth and at weaning. The pattern used to determine the fertility traits of rabbit does according to Rabbitry records are shown in Table 2. BB and NZW rabbit bucks characterized by low-fertilizing ability were also, separated from those with high-fertilizing ability using libido and physical semen characterized represented in (semen-ejaculate volume, mass and advanced sperm motility, percentages of dead and abnormal spermatozoa and acrosomal damages and sperm-cell concentration per $\mathrm{ml}$ and per ejaculate), in addition according to mating activity, scrotal circumference and testicular index. The pattern used to evaluate fertilizing ability of rabbit bucks as recorded by physical semen characteristics are shown in Table 3.

Sixty sexually mature rabbits (30 in each of low-fertile and high-fertile) of twelve months of age (10 does \& 5 bucks of each breed of Baladi Black "BB" and New-Zealand White "NZW") were used in this study. 
Table 2. The pattern used to determine the fertility traits of rabbit does according to Rabbitry records.

\begin{tabular}{|l|c|c|}
\hline \multirow{2}{*}{\multicolumn{1}{|c|}{ Items }} & \multicolumn{2}{c|}{ Fertility traits } \\
\cline { 2 - 3 } & Low-fertile & Ordinary-fertile \\
\hline Abortion rate (\%) & $\geq 03.00$ & $<03.00$ \\
Conception rate (\%) & $\leq 60.00$ & $>60.00$ \\
Kindling rate (\%) & $\leq 57.00$ & $>57.00$ \\
Litter size at birth (No.) & $\leq 04.75$ & $>04.75$ \\
Litter weight at birth (g) & $\leq 200.0$ & $>200.0$ \\
Bunny weight at birth (g) & $\leq 40.00$ & $>40.00$ \\
Litter size at weaning (No.) & $\leq 04.00$ & $>04.00$ \\
Litter weight at weaning (g) & $\leq 2250$ & $>2250$ \\
Bunny weight at weaning (g) & $\leq 0550$ & $>0550$ \\
\hline
\end{tabular}

Table 3. The pattern used to evaluate fertilizing ability of rabbit bucks.

\begin{tabular}{|l|c|c|}
\hline \multirow{2}{*}{\multicolumn{1}{|c|}{ Items }} & \multicolumn{2}{c|}{ Fertilizing ability } \\
\cline { 2 - 3 } & Low-fertile & Ordinary-fertile \\
\hline Libido (Sec.) & $\geq 40.00$ & $<40.00$ \\
Mass sperm motility (Score) & $\leq 02.50$ & $>02.50$ \\
Advanced sperm motility (\%) & $\leq 50.00$ & $>50.00$ \\
Dead spermatozoa (\%) & $\geq 35.00$ & $<35.00$ \\
Sperm abnormalities (\%) & $\geq 30.00$ & $<30.00$ \\
Acrosomal damages (\%) & $\geq 25.00$ & $<25.00$ \\
Semen ejaculate volume (ml) & $\leq 00.40$ & $>00.40$ \\
Sperm-cell concentration (N X 106/ ml) & $\leq 450.0$ & $>450.0$ \\
Total-sperm output (N X 106/ ejaculate) & $\leq 180.0$ & $>180.0$ \\
Mating activity (no. of mating/ 20 minutes) & $\leq 02.50$ & $>02.50$ \\
Scrotal circumference (Cm) & $\leq 07.00$ & $>07.00$ \\
Testicular index (Cm3) & $\leq 06.50$ & $>06.50$ \\
\hline
\end{tabular}

\section{Experiment 2:}

It was planned to measure Lipten hormone concentration in blood serum of doe and buck of BB and NZW rabbits. Lipten hormone levels in milk, during lactating period of $\mathrm{BB}$ and NZW rabbit does were recorded weekly up to the $5^{\text {th }}$ week, as well as, Lipten hormone levels were estimated in $1^{\text {st }}$ and $2^{\text {nd }}$ semen ejaculated by BB and NZW rabbit bucks. Lipten hormone levels were measured in ordinary and low-fertile does and in bucks of high and low- 
fertilizing ability of two rabbit breeds used in the study.Five bucks and ten does within both high and low-fertile of each rabbit breed used in the study were conducted to determine Lipten hormone levels in blood, semen or milk.

\section{Measurement of Leptin hormone concentration}

Leptin hormone concentration in blood serum and milk and seminal plasma was done using DRG® Leptin (Sandwich) ELISA (EIA-2395). The DRG ${ }^{\circledR}$ Leptin ELISA commercial kit is a solid phase enzyme-linked immunosorbent assay (ELISA) accordin to Considine and Sinha (1996) and Guillaume and Bjorntorp (1996).

\section{Blood collection}

Blood samples were collected from the marginal ear vein of 3 does and 3 bucks of eachexpermental group after shaving and cleaning with alcohol. A spring lancet made of steel sheets puncture was used to get an adequate but not profuse flow of blood. Blood samples were collected at the morning between 8.00 to $10.00 \mathrm{a} . \mathrm{m}$. as stated by Thompson and Proctor (1984).

Blood samples were collected into dry clean heparinzed centrifuge tubes. With heparin film to prevent the blood coaggulant. Blood serum was separated by centrifugation at 3000 r.p.m. for 20 minutes and kept in a deep freezer at -20C until analysis.

\section{Semen collection}

Semen was collected using artificial vagina between 08.00 to 10.00 a.m. As described by Waston

\section{Semen evaluation}

Libido and physical semen characteristics represented in values of each of semen-ejaculate volume; mass and advanced sperm motility; percentages of sperm abnormalities; dead spermatozoa and acrosomal damages and spermcell concentration per $\mathrm{ml}$ and per ejaculate were evaluated. Physical semen characteristics were evaluated according to Campbell et. al. (1956);Hackett and Macpherson (1965); Watson (1975); Salisburyet. al (1978) and Seleem et al. (2009).

Mating activity of rabbit buck was done as studied by Badawi et. al. (2010). Scrotal circumference wasmeasured by measuring the circumference of scrotum of each testis of each BB and NZW rabbit bucks as the method 
described by Mickelsen et. al. (1982).Testicular index (length xwidth $\mathrm{x}$ depth) was calculated in cubic centimeters as recorded by El-Kholy et. al. (2012).

Statistical analysis

Data were statistically analyzed using Least Squares Analysis of Variance according to Snedecor and Cochran (1967). Percentage values were transformed to arcsin values before being statistically analyzed. Duncan's Multiple Range Test (Duncan, 1955) was used to compare the differences between significant means. Conception and kindling rates were analyzed using Contingency tables according to Everitt (1977).

\section{RESULTS AND DISCUSSIONS}

\section{Leptin Hormone levels in blood}

Data presented in Tables (4 and 5) showed that, Leptin hormone concentration in blood serum of ordinary fertile doe and buck rabbits were significantly $(\mathrm{P} \leq 0.5$ or 0.1$)$ higher than those recorded in low fertile ones. This trend was recorded in both two studied breeds (BB and NZW) rabbits., BB rabbits recorded Leptin hormone levels insignificantly higher than those obtained by NZW rabbits. For both high and low fertile or both does and bucks.

\section{Leptin Hormone levels in milk}

Table 6 clearly showed that, ordinary fertile BB and NZW lactating rabbit does produced milk with Leptin hormone concentrations significantly highly $(\mathrm{P} \leq 0.01)$ those recorded by low fertile rabbits, during nursing period from kindling up to 5 weeks. BB rabbit does show values of leptin hormone concentrations insignificantly superior than those recorded by NZW ones.

\section{Leptin Hormone levels in semen}

Data presented in Table 7 showed that, semen ejaculated by high fertile BB and NZW rabbit bucks included Leptin hormone concentrations highly significant $(\mathrm{P} \leq 0.01)$ higher than those of low fertile bucks. BB rabbit bucks and second ejaculates characterized by Leptin hormone levels insignificantly higher than those obtained by NZW rabbit bucks and first ejaculates, respectively. 
Table 4. Leptin hormone levels in blood (ng/ dl) of low and high fertile rabbit does (Means \pm SE).

\begin{tabular}{|l|c|c|c|}
\hline \multirow{2}{*}{ Breeds } & \multicolumn{2}{|c|}{ Fertility traits } & \multirow{2}{*}{ Means \pm SE } \\
\cline { 2 - 3 } & Low-fertile & high-fertile & \\
\hline BB & $2.47 \pm 0.42$ & $3.84 \pm 0.51$ & $3.16 \pm 0.44$ \\
NZW & $2.36 \pm 0.37$ & $3.61 \pm 0.54$ & $2.99 \pm 0.49$ \\
\hline Means \pm SE & $2.42 \pm 0.63 \mathrm{~b}$ & $3.73 \pm 0.53 \mathrm{a}$ & $3.07 \pm 0.57$ \\
\hline
\end{tabular}

Means bearing different letter superscripts within the same row are significantly $(\mathrm{P} \leq 0.01)$ differ

Table 5. Leptin hormone levels in blood (ng/ dl) of low and high fertile rabbit bucks (Means \pm SE).

\begin{tabular}{|l|c|c|c|}
\hline \multirow{2}{*}{ Breeds } & \multicolumn{2}{|c|}{ Fertility traits } & \multirow{2}{*}{ Means \pm SE } \\
\cline { 2 - 3 } & Low fertile & high fertile & \\
\hline BB & $2.34 \pm 0.37$ & $3.62 \pm 0.52$ & $2.98 \pm 0.41$ \\
NZW & $2.24 \pm 0.33$ & $3.43 \pm 0.54$ & $2.84 \pm 0.40$ \\
\hline Means \pm SE & $2.29 \pm 0.34 \mathrm{~b}$ & $3.53 \pm 0.50 \mathrm{a}$ & $2.91 \pm 0.46$ \\
\hline
\end{tabular}

Means bearing different letter superscripts within the same row are significantly $(\mathrm{P} \leq 0.01)$ differ.

Table 6. Leptin hormone concentration in milk (ng/ dl) of low and high fertile rabbit does (Means \pm SE).

\begin{tabular}{|c|c|c|c|c|}
\hline \multirow{2}{*}{ Milk period } & \multirow{2}{*}{ Breeds } & \multicolumn{2}{|c|}{$\begin{array}{l}\text { Fertility traits } \\
\end{array}$} & \multirow{2}{*}{ Means \pm SE } \\
\hline & & Low-fertile & highcc-fertile & \\
\hline \multirow{2}{*}{$1^{\text {st }}$ week } & BB & $1.93 \pm 0.27$ & $3.36 \pm 0.59$ & $2.65 \pm 0.36$ \\
\hline & NZW & $1.84 \pm 0.19$ & $3.28 \pm 0.62$ & $2.56 \pm 0.21$ \\
\hline \multicolumn{2}{|l|}{ Means $\pm \mathrm{SE}$} & $1.89 \pm 0.26 \mathrm{~b}$ & $3.32 \pm 0.54 \mathrm{a}$ & $2.61 \pm 0.33$ \\
\hline \multirow{2}{*}{$2^{\text {nd }}$ week } & BB & $2.51 \pm 0.32$ & $3.69 \pm 0.70$ & $3.10 \pm 0.42$ \\
\hline & NZW & $2.32 \pm 0.34$ & $3.64 \pm 0.63$ & $2.98 \pm 0.52$ \\
\hline \multicolumn{2}{|l|}{ Means \pm SE } & $2.42 \pm 0.33 \mathrm{~b}$ & $3.67 \pm 0.68 \mathrm{a}$ & $3.04 \pm 0.51$ \\
\hline \multirow{2}{*}{$3^{\text {rd }}$ week } & BB & $2.64 \pm 0.44$ & $3.99 \pm 0.58$ & $3.32 \pm 0.54$ \\
\hline & NZW & $2.41 \pm 0.51$ & $3.92 \pm 0.48$ & $3.17 \pm 0.47$ \\
\hline \multicolumn{2}{|c|}{ Means \pm SE } & $2.53 \pm 0.46 \mathrm{~b}$ & $3.96 \pm 0.56 \mathrm{a}$ & $3.24 \pm 0.50$ \\
\hline \multirow{2}{*}{$4^{\text {th }}$ week } & BB & $2.11 \pm 0.38$ & $3.47 \pm 0.47$ & $2.79 \pm 0.40$ \\
\hline & NZW & $2.01 \pm 0.30$ & $3.18 \pm 0.40$ & $2.60 \pm 0.34$ \\
\hline \multicolumn{2}{|l|}{ Means \pm SE } & $2.06 \pm 0.31 \mathrm{~b}$ & $3.33 \pm 0.46 \mathrm{a}$ & $2.70 \pm 0.33$ \\
\hline \multirow{2}{*}{$5^{\text {th }}$ week } & BB & $1.86 \pm 0.25$ & $3.14 \pm 0.59$ & $2.50 \pm 0.29$ \\
\hline & NZW & $1.79 \pm 0.18$ & $2.95 \pm 0.46$ & $2.37 \pm 0.22$ \\
\hline \multicolumn{2}{|c|}{ Means \pm SE } & $1.83 \pm 0.22 \mathrm{~b}$ & $3.05 \pm 0.51 \mathrm{a}$ & $2.44 \pm 0.33$ \\
\hline \multicolumn{2}{|c|}{ Overall means $\pm \mathrm{SE}$} & $2.15 \pm 0.24 \mathrm{~b}$ & $3.47 \pm 0.46 \mathrm{a}$ & $2.81 \pm 0.27$ \\
\hline
\end{tabular}

Means bearing different letter superscripts within the same row are significantly $(\mathrm{P} \leq 0.05$ or 0.01$)$ differ. 
Table 7. Leptin hormone concentration in semen (ng/ dl) low and high fertile rabbit bucks (Means \pm SE).

\begin{tabular}{|c|c|c|c|c|}
\hline \multirow{2}{*}{$\begin{array}{c}\text { Semen } \\
\text { ejaculated }\end{array}$} & \multirow[b]{2}{*}{ Breeds } & \multicolumn{2}{|c|}{ Fertility traits } & \multirow[b]{2}{*}{ Means \pm SE } \\
\hline & & Low-fertile & $\begin{array}{c}\text { Ordinary- } \\
\text { fertile }\end{array}$ & \\
\hline $1^{\text {st }}$ ejaculate & $\begin{array}{c}\text { BB } \\
\text { NZW }\end{array}$ & $\begin{array}{l}2.07 \pm 0.28 \\
2.02 \pm 0.31\end{array}$ & $\begin{array}{l}3.21 \pm 0.42 \\
3.09 \pm 0.33\end{array}$ & $\begin{array}{l}2.64 \pm 0.33 \\
2.56 \pm 0.30\end{array}$ \\
\hline \multicolumn{2}{|l|}{ Means \pm SE } & $2.05 \pm 0.28 \mathrm{~b}$ & $3.15 \pm 0.36 \mathrm{a}$ & $2.60 \pm 0.31$ \\
\hline $2^{\text {nd }}$ ejaculate & $\begin{array}{c}\text { BB } \\
\text { NZW }\end{array}$ & $\begin{array}{l}2.22 \pm 0.19 \\
2.16 \pm 0.24\end{array}$ & $\begin{array}{l}3.48 \pm 0.44 \\
3.26 \pm 0.29\end{array}$ & $\begin{array}{l}2.85 \pm 0.26 \\
2.71 \pm 0.22\end{array}$ \\
\hline \multicolumn{2}{|c|}{ Means \pm SE } & $2.19 \pm 0.20 \mathrm{~b}$ & $3.37 \pm 0.33 \mathrm{a}$ & $2.78 \pm 0.24$ \\
\hline \multicolumn{2}{|c|}{ Overall means $\pm \mathrm{SE}$} & $2.12 \pm 0.17 \mathrm{~b}$ & $3.26 \pm 0.33 \mathrm{a}$ & $2.69 \pm 0.21$ \\
\hline
\end{tabular}

Means bearing different letter superscripts within the same row are significantly $(\mathrm{P} \leq 0.05$ or 0.01 ) differ.

Zhang et al. (1994) identified the mutated protein, Lipten, in mice, which is assumed to be the circulating satiety signal. Lipten has additional physiological activities, including activation of the sympathetic nervous system, regulation of reproductive function, and activation of the immune system (Zhang et al., 1994). In human; reported that, Lipten concentrations in whole and skim milk were correlated with maternal plasma lipten concentrations. From early to mid-pregnancy, circulating Lipten levels increased and remained elevated until late pregnancy in sheep. In mares, Romagnoliet al. (2007) found that, the highest cholesterol lipten level recorded during the week of parturition compared with two weeks before parturition. On the other hand, in sows Huszeniczaet al. (2002) and Smith and Grove (2002) reviewed that, negative energy balance during lactation is reflected by decreases in serum Lipten and thyroid hormone levels. At this time, it is unclear and poorly documented, what mechanisms may be responsible for the suppression of thyroid hormones and whether there is a link to the suppression of Lipten.

New Zealand White rabbits, as well known in Egypt as a meat purpose breed that intensively spread all over the country Ayyat and Marai (1998) have indicated that, Baladi Black rabbits as a local meat type breed are widely and more adapted with Egyptian environmental conditions.

Khalil et al. (1988) and Hilmy (1991) scored that, local Baladi Black rabbits, which assumed to be adapted to the Egyptian conditions have 
different genetic basis among foreign breeds. On the other hand, found NZW rabbit breed characterized by productive and reproductive superior than Baladi Black ones. Direct genetic effects of exotic breeds compared to Baladi ones are favorable in letters at birth and during the first 21 days of sucking but not at weaning (Afifi and Khalil, 1991). New Zealand White bucks generally produce litters with larger size and heavier weight along with heavier mean bunny weight at birth and at 21 days of age than do the Baladi bucks (Youssef, 1992).

The study current concluded that, there was strongly correlation between Leptin hormone concentration in each of (blood, semen and milk) and rabbit reproductivity. BB rabbits recorded Leptin hormone levels insignificantly higher than those of NZW rabbits, so BB rabbits may be characterized by reproductive capability more than NZW rabbits, under the environmental conditions of conducting that experiment.

Coclusively, it could be concluded that, there was strongly correlation between Leptin hormone concentration in blood, semen and milk and rabbit reproductivity. BB rabbits recorded Leptin hormone levels insignificantly higher than those of NZW rabbits, so BB rabbits may be characterized by reproductive capability more than NZW rabbits.

\section{REFERENCES}

Afifi, E.A. and Khalil, M.H. (1991). Crossbreeding experiment rabbits in Egeypt. Synthesis of Seminaries, 17: 32-35, Spain.

Badawi, Y.K.; T.S.T. Seleem; A. Farid; Kh.A.A. Ali; S. El-Mola and A.A. Abd El Aziz (2010). Rabbit production under poluted environmental conditions: 4. effect of electromagnetic waves pollution on rabbits performance and its alleviation using propolis during mature period. The $6^{\text {th }}$ Inter. Conf .on Rabbit Prod. in Hot Clim., Assuit, Egypt, 569- 585.

Campbell R. C.; H. M. Dott and T. D. Glover (1956). Nigrosin-eosin as stain for differentiating live and dead spermatozoa, J. Agric. Sci., 48:1-8.

Considine, R.V. and M.K. Sinha (1996). Serum Immunoreactive-Leptin concentration in normal weight and Obese Humans. New England Journal of Medicine, February. 
Daader, A.H. and T.ST. Seleem (1999). Recent trends in rabbit production. 1st International Conference. on Indigenous Versus Acclimatized Rabbits, 7-9 Sept., El-Arish, North-Sinai, Egypt, 23-50.

Duncan W. R. (1955). Multiple range and multiple (F-test), Biometrics, 11:1-42.

El-Kholy, K. H.; S.Z. El-Damrawy and T.S.T. Seleem (2012). Rabbit productivity and reproductivity as affected by cinnamon (CinnamomumZeylanicum). Egyptian Poultry Science, (32) (IV): 691-703.

Everitt B. S. (1977). The analysis of Contingency Tables. Monographs of Applied Probability and Statistics, London, 38-66.

Galal, E.S.E. and M.H. Khalil (1994). Development of rabbit industry in Egypt. 1st Inter-Conf. on Rabb. Prod. in Hot Climates, 6-8 Sept., Cairo, Egypt., 43-56.

Guillaume, M. and P. Bjorntorp (1996). Obesity in children: Environmental and genetic aspects. Horm. Metab. Res., 28: 573-581.

Hackett A. J. and J. W. Macpherson (1965). Some staining procedures for spermatozoa, Canadian Vet. Journal, 6:55-62 (A review).

Hilmy, A.F. (1991). Some productive aspects in rabbits. M.Sc. Thesis, Fac. Agric., Zagazig Un., Banha Branch, Moshtohor, Egypt.

Huszenicza, G.; M. Kulcsar, and P. Rudas. (2002). Clinical endocrinology of thyroid gland function in ruminants. Vet. Med.Czech, Vol. 47, (7): 199-210.

Khalil, M.H. (1999). Rabbit genetic resource in mediterranean countries. Option Mediterraneennes, Serie B,. 38: 39-50.

Mickelsen, W. D.; L. G. ,Paisley and J. J.,Dahmen (1982). The relationship of libido and serving capacity test score in rams on conception and lambing percentage in the ewe. Theriogenology, 18: 79.

NRC (1994). Nutrient Requirements of Rabbits. 2nd Ed. National Academy of Science, Washington, DC. USA.

Romagnoli, U., E. Macchi, G. Romano, M. Motta, P. Accornero, and M. Baratta. (2007). Short communication: Leptin concentration in plasma and in milk during the interpartum period in the mare. Animal Reproductrion Science, 97: 180-185. 
Rowida, M. Riad and T.S.T. Seleem (2007). Effect of intramuscularly injection of Gn-RH on some reproductive trait of male and female rabbits to improve artificial insemination. The 5th Inter. Conf. on Rabbit Prod. In Hot Clim., Hurghada, Egypt, 369-379.

Rowida, M. Riad; T.S.T. ,Seleem and Dalal S.E. Mohamed (2010). The relation between type of mating and reproductive performance of rabbit under Egyptian condition. The 6th Inter. Con .on Rabbit Prod. in Hot Clim., Assuit, Egypt, 413-426.

Salisbury ,G. W.; N. L. ,Van Demark and J. R. ,Lodge (1978). Physiology of reproduction and artificial insemination of cattle, W. H. Freeman Company, San Francisco, U.S.A.

Seleem, T. S. T.; Fayek, H.M.; El-Kholy, K. H. and Afifi, S. M. (2007). Rabbit productivity and reproductivity as influenced by prebiotics in drinking water. 4th Worlds Poultry Conferences, Sharm El-Shekh, Egypt, March 27-30: 603-625.

Seleem, T.S.T.; A. E. M. Abd El-Motaal and K. H. El-Kholy (2006). Effect of L-carnitine preparation in drinking water on some productive and reproductive performance of NZW rabbits. The 1st Conference on Clean Environment and Safety Food, December, Ain Shams University, Egypt.

Seleem, T.S.T.; H. Ibrahim and Hedia El-Saieed (2009). Effect of diluents ph on rabbit semen quality, during preservation and artificial insemination. The 5th International Poultry Conference, 10-13 March, Taba, Egypt.

Snedecor G. W. and W. G. Cochran (1967). Statistical Methods, 2nd edn. Iowa Univ. Press. Ames, Iowa.

Thompson, R. B. and S. J., Proctor (1984). A Short Text Book Of Haematology, 6th edn. English language, Book Society, Pitman.

Watson, P F. (1975). Use of Giemsa stain to detect changes in acrosomes of frozen ram spermatozoa, Vet. Res., 97:12-15.

Youssef, Y.M.K. (1992). The productive performance of purebred and cross bred rabbits. M.Sc. Thesis, Faculty of Agriculture, Moshtohor, Zagazig University, Banhan Branch, Egypt. 
Zaki, T.G.; A.E.B. ,Zeidan And T.S.T. ,Seleem (2000). Some physiological and reproductive aspects of Baladi Red buck rabbits fed Fenugreek or Nigella Sativa, under hot climates. Conf. Erence of Social and Agriculture Development of Sinai, 16-19 May, El-Arish, North. Sinai, 89-99.

Zhang, Y., R. Proenca, M. Maffei, M. Barone, L. Leopold and J. M. Friedman (1994). Positional cloning of the mouse obese gene and its human homologue. Nature, 372: 425-432.

\section{العلاقة بين تركيز هرمون اللبتين والتناسل فى الأرانب}

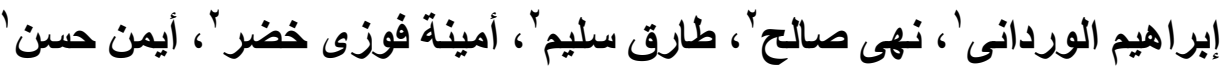

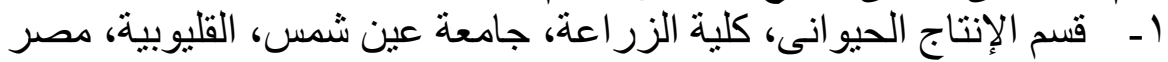

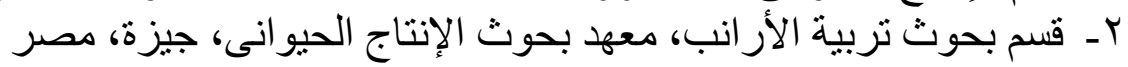

صمم هذا البحث لدراسة العلاقة بين تركيز هرمون اللبتين والتناسل فى التى الأرانب. وقد أستخدم سلالتين من الأرانب (البلدى الأسود كسلالة محلية،

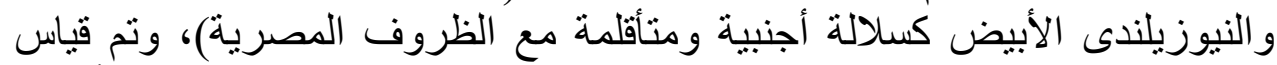

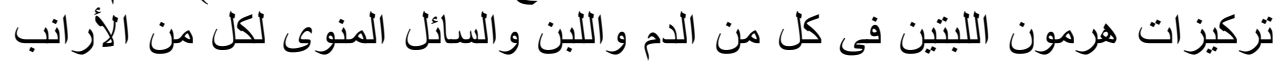
وقد إثتملت الدراسة على تجربتين أساسيتين، أجريت التجربة الأولى لتحديد

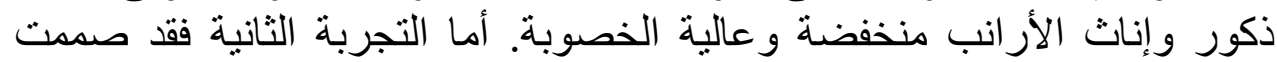
لقياس تركيزات هرمون اللبتين المختلفة فى دم ذكور وإناث الأنة الأرانب منخفضة التهانة و عالية الخصوبة وكذلك تم قياس مستويات هرمون اللبتين فى لبن البن الأمهات

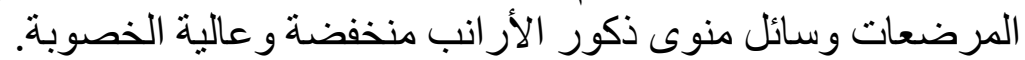

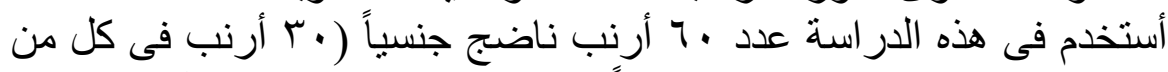

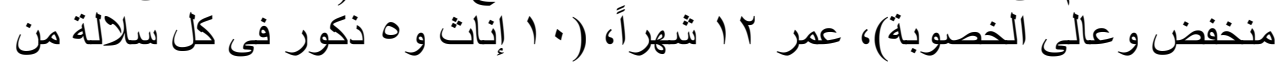
البلدى الأسود و النيوزيلندى الأبيض)، عمدر) 


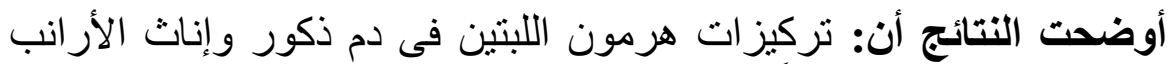

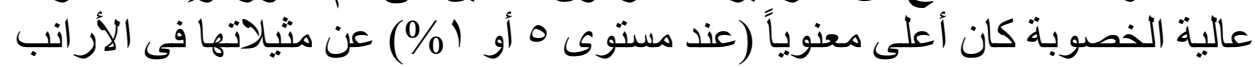

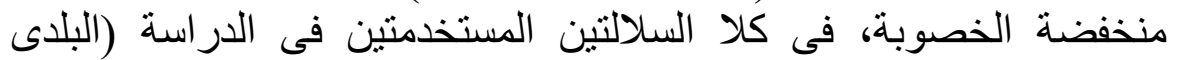

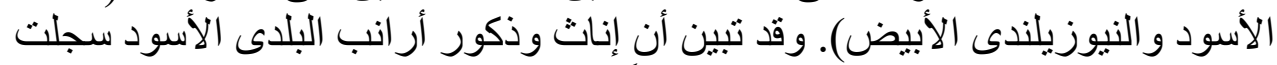

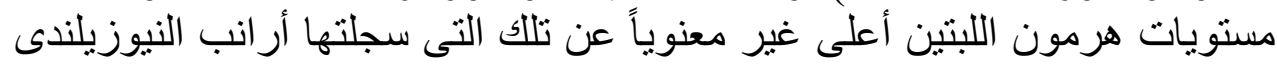
الأبيض، فى كلا الحالتين تحت الدر اسة (منخفضة التينة و عالية الخصوبة).

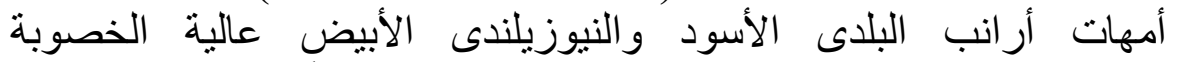

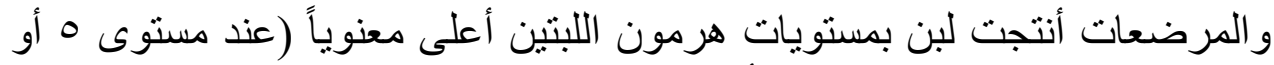

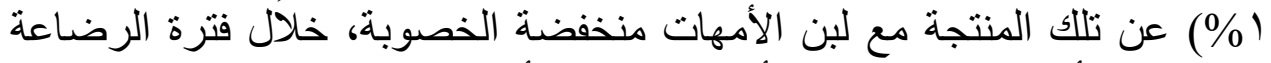

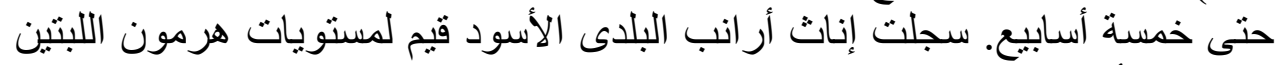

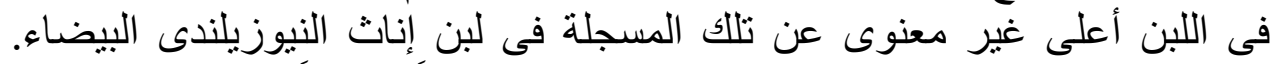

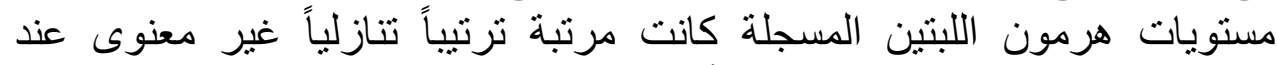

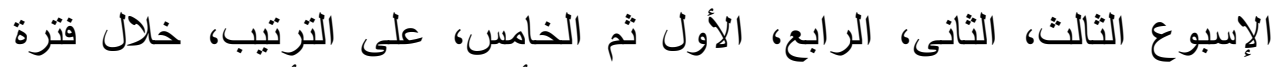

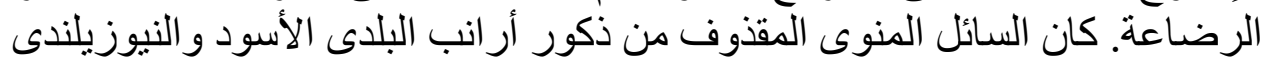

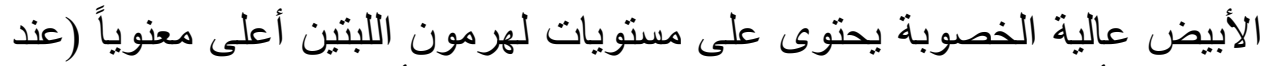

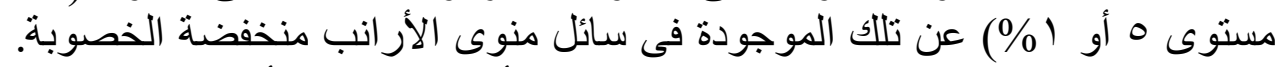

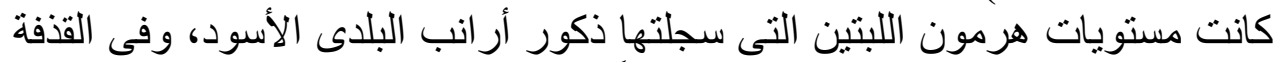

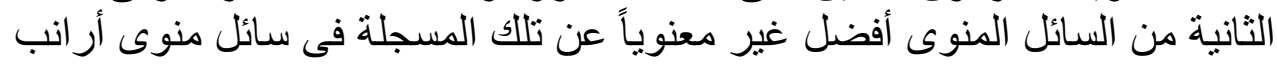

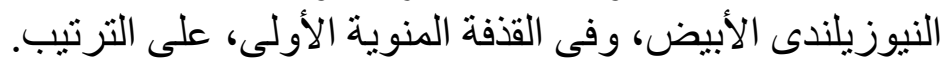

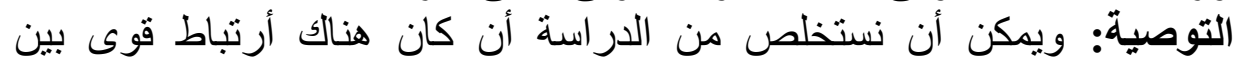

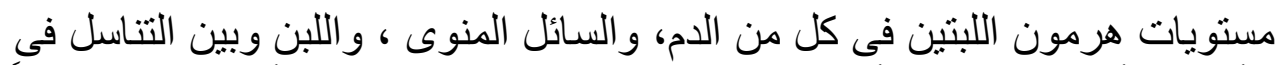

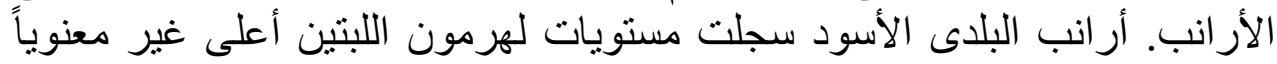

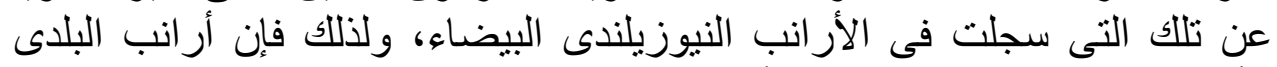
الأسود ربما تمتاز بمقدرة تناسلية أعلى عن النيوزيلندى البيضاء. لإنياء. 
Egyptian Journal of Rabbit Science, 26(1): 121 - 134 (2016) 